\title{
大人による要求身ぶりの模倣が前言語期の重度精神遅滞児との 交渉に及ぼす効果
}

\begin{abstract}
大井学
重度精神遅滞児の非指示身ぶりによる要求伝達における大人との交涉に、大人からの身ぶ り模倣が及ほす効果を検討するため、子ども及び相手の大人 4 組を対象とする単一事例研究 を行った。大人はベースライン期では子供の要求身ぶりに通常のやり方で応答すること、模 做期では要求身ぶりを模倣することを求められた。3名の子供はベースライン期には大人の 応答に対する受容をまったく表現せず、1 名は伝達の 3 分の 1 で受容を表現した。模做期には 4 名ともほとんどの伝達で受容を表現するようになり、子供の身ぶり、大人からの模倣、子供 の受容の表現の 3 ターンからなる交涉が成立した。そこでは、大人による身ぶりの模做が要 求に対する肯定を意味することが子どもに理解されたと考えられた。交涉の成立と平行して 身ぶりの際に大人を見ることが 3 名の子供で増加した。この視線は身ぶり模倣の有無を確か めるものと考えられた。
\end{abstract}

キー・ワード：重度精神遅滞 前言語的伝達 要求身ぶり 交渉

\section{I 、はじめに}

前言語段階の子供と大人がコミュニケーションにお いてどのように協力しあっているかという問題には、 ようやく関心が寄せられ始めたところである。最近の 研究は、大人が早い時期から子供に会話の規則への接 近を促して扔り、子供もそれに従おうとしていること を示唆している (Golinkoff, 19862); 木下, 19873); 大 井, 19909); Tomasello, Conti-Ramsden, and Ewert, $\left.1990^{111}\right)$ 。すなわち、話し手が自らの表現を明確にし、 聞き手の理解を見守り、聞き手の解釈の正否について 知らせていくという会話の協力の原理、コミュニケー ションは話し手の伝達意図が聞き手に認識されること を通じて達成されるという「共有の知識」(Levinson, $\left.1983^{4)}\right)$ の概念に、子供は前言語段階から接近し始めて いると考えられる。

12 力月児の母親に対する伝達について検討した Golinkoff $\left(1986^{2)}\right)$ は、母親と子供との間に2つの協 カパタンがあることを見いだした。第 1 は、子供の伝 達、母親からの解釈の提供、それに対する子供の受容 の表現という、3つのターンからなる最小限の交涉で あり、第 2 は、母親からの明確化要請に応じるなど、

金沢大学教育学部
子どもが伝達の失敗を修正 (repair) する努力を、伝達 が成功するまで 7 ターン以上にわたつて行う複雑な交 涉である。子供から開始された伝達の $40 \%$ 弱が第 1 の、50\%強が第2のパタンを示した。Bruner $\left(1983^{11}\right) 、$ McTear and Conti-Ramsden $\left(1992^{7)}\right)$ は、このよう な大人と協力しながら自らり意図を実現していく交涉 の経験が、子供にとってコミュニケーションと言語に ついて学ぶ重要な機会となっているとみなしている。

ところが前言語段階にある重度精神遅滞児・者の場 合は、大人と子供の協力が必ずしもうまくはいってい ないようである。McLean, McLean, Brady, and Etter $\left(1991^{5)}\right)$ は、指示身ぶりがそしく渡すなどの接触身ぶ りしかもたない重度遅滞成人は、伝達の失敗の修正 (repair)が乏しいことを見いだした。また重度精神遅 滞児の合掌身ぶりによる要求伝達を検討した大井 $\left(1992^{10)}\right)$ は、身ぶり直後に大人が要求を満たしてしま うために交渉が起きなかったり、大人の言語応答に対 して子供が身ぶりを反復するにとどまり、交涉が行き 詰まったりしていることを見いだした。

大井 $\left(1992^{10)}\right)$ のとりあげた子供においては、合掌身 ぶりを大人が模做するようにすると、交涉が成立する ことが見いだされた。すなわち大人が身ぶりを模倣す ると、子どもは合掌身ぶりを反復したりせず、目標と 
大井学

Table 1 対象児の発達状態

\begin{tabular}{|c|c|c|c|c|}
\hline & A 児 & B児 & C児 & D児 \\
\hline 暦年齢 & 7 歳 7 力月 & 6 歳 5 力月 & 5 歳11力月 & 9 歳 5 力月 \\
\hline $\begin{array}{l}\text { 発達年齢 } \\
\text { またはは } \\
\text { 精神年齢 }\end{array}$ & $\begin{array}{c}1 \text { 歳 } 4 \text { 力月 } \\
\text { (新版 K式検査・ } \\
\text { 認知一適応) }\end{array}$ & $\begin{array}{l}1 \text { 歳 } 5 \text { 力月 } \\
\text { (津守式) }\end{array}$ & $\begin{array}{c}1 \text { 歳 } 9 \text { カ月 } \\
\text { (津守式) }\end{array}$ & $\begin{array}{l}1 \text { 歳10カ月月 } \\
\text { (田中ビネー) }\end{array}$ \\
\hline 物の概念 & $\mathrm{V}$ & V & VI & VI \\
\hline 因果性 & V & V & $\mathrm{V}$ & VI \\
\hline 手段と目的 & $\mathrm{V}$ & V & VI & $\mathrm{VI}$ \\
\hline 要求身ぶり & $\begin{array}{c}\text { 兩手吅き } \\
\text { 大人手を持つ }\end{array}$ & $\begin{array}{c}\text { 両手叨き } \\
\text { 挙手 } \\
\text { 大人の手を持つ }\end{array}$ & $\begin{array}{c}\text { 両手吅き } \\
\text { 指さし } \\
\text { 大人の手を持つ }\end{array}$ & $\begin{array}{c}\text { 合掌 } \\
\text { 到達行動 }\end{array}$ \\
\hline $\begin{array}{l}\text { 絵画語彙検査の } \\
\text { 語彙年噛量 }\end{array}$ & 不能 & 不能 & 不能 & 2 歳 2 力月 \\
\hline
\end{tabular}

物の概念, 困果性, 手段と目的の評価はMiller, Chapman, Branton, and Reichle $\left(1980^{8}\right)$ によっ た. V, VIはpiagetの感覚運動知能の第 5 , 第 6 階にあたる課題が達成されたことを示す

していた行動に向かおうとするようすを見せた。子ど もは大人の身ぶり模做を見て、大人が要求を受け入れ、 それを充足しようとしていると考えたようである。ま た子供は合掌身ぶりの際に大人を見るようになった。 これは自らの合掌身ぶりに対して大人が模做するかど うかを確かめようとしたものと思われた。これらから、 大人の身ぶり模做が要求に対する肯定を意味すること を子供が理解したものと考えられた。交涉が成立して 以後、大人からの明確化要請に対して子供が修正 （repair）を行うなどのより展開された交涉が行われ るようになり、指さしの使用など伝達技能が改善され た。

こうした交涉の成立と展開は、Golinkoff $\left(1986^{2)}\right)$ が示した協力の 2 つのパタンが形成されたものとみな されるかもしれない。特に、身ぶり模倣の導入によっ て最初に成立した交渉は、3つのターンからなるとさ れる第 1 パタンと似ているように思われる。それを確 かめるには、第 2 ターンで大人が身ぶりを模倣した場 合の、第 3 ターンにおける子供の伝達行動がどのよう なものかを検討しなければならない。Golinkoff は第 1 のパタンの第 3 ターンを、大人が提供する解釈に対 する子供からの受容の表現とし、それを「最初の身ぶ りを停止し、身ぶり前の目標行動に向かう動きを応答 後に再開する」ものと定義している。

なお、Golinkoff $\left(1986^{2)}\right)$ の第 1 パタンの第 2 ター ンでは大人は言語によって解釉を提供しており、子供 はそれを聞いて受容している。これに対し身ぶり模倣 の場合は、それを見なければ受容できない。子供が大
人の身ぶり模倣に対して受容を表現するようになると すれば、自らの要求身ぶりの際に大人を見ることも、 それにともなって増えるものと考えられる。

本研究では、合掌などの非指示身ぶりによる重度精 神遅滞児の要求伝達において、大人からの通常の応答 に対して子供は受容を表現しないのかどうか、大人に よる身ぶりの模倣が導入されれば受容を表現するよう になるのかどうか、すなわち身ぶり模倣の導入前後で 最小限の交涉の成否に変化があるかどうかを明らかに しょうとした。またそれにともなって大人を見ながら 身ぶりすることが増えるかどうかも明らかにしょうと した。そのために 4 組の重度精神遅滞児と大人を対象 として、ベースライン $(\mathrm{A})$ と処理 $(\mathrm{B}$ ：この場合は身 ぶり模倣）からなる $\mathrm{AB}$ デザインによる単一事例研究

(McReynolds and Kearns, 19836) ) が行われた。

\section{II. 方 法}

\section{1. 観察の対象}

1 つの通園施設及び養護学校学校小学部低学年 1 学 級から、重度精神遅滞があり要求伝達の主な手段が非 指示身ぶりであるという基準で抽出された 3 名（以下 A 児, B 児, C 児)、及び要求伝達を主に合掌によって 行うことが大井 $\left(1992^{10)}\right)$ により見いだされていた 1 名 (以下 D 児)、計 4 名の大人に対する要求伝達を観察 した。 4 名の年齢、発達状態は Table 1 に示した。子供 の抽出を依頼するにあたって、非指示身ぶりとしては 合掌、両手吒き、掌を上に向ける両手合わせを例示し たが、A 児、B児及び $\mathrm{C}$ 児は主に両手吒きを用いてい 
大人による要求身ぶりの模做が前言語期の重度精神遅帯児との交涉に及ぼす効果

Table 2 要求伝達についてのターン毎の文字転写の例

\begin{tabular}{|c|c|}
\hline 供 & 大 \\
\hline \multicolumn{2}{|l|}{$\begin{aligned} \text { 第 } 3 \text { 週 (ベースライン期) : ブランコ } \\
\quad \text { (ブランコから } 2 \text { メートル離れた所で })\end{aligned}$} \\
\hline 3. 大人の手を持って引っ張る & 2.「なあに」 \\
\hline \multicolumn{2}{|c|}{$\begin{array}{l}\text { 第 } 9 \text { 週（模倣期）：ブランコの要求に対する身ぶり模做 } \\
\quad \text { (子供はブランコから立ち上がり，2メートル離れている大人に近づく） }\end{array}$} \\
\hline \multicolumn{2}{|l|}{ 3. ブランコに向かって歩く } \\
\hline \multicolumn{2}{|c|}{$\begin{array}{c}\text { 第 } 9 \text { 週（模做期）：オンブの要求に対する腕組 } \\
\text { (大人の正面 } 2 \text { メートルの所から） }\end{array}$} \\
\hline 1. 大人の方を向いて両手を吅く & 2.「ブー」と腕をクロスしてみせる \\
\hline 3. 大人に近づき両手をとって合わさせる & \\
\hline
\end{tabular}

子供はA児である. 文頭の数字はターン番号を示す

た。 4 名とも感覚運動的知能の「物の概念」、「因果性」 及び「手段と目的」の 3 領域で第 5 段階以上に達して いた。しかし発達状態は等質ではなく、A 児と B 児は 3 領域とも第 5 段階であるのに対し、C 児と D 児は 2 ないし 3 領域で第 6 段階に達していた。D 児には視覚 障害があったが、他の 3 名は視覚に特別の問題がな かった。D巟は右眼が光覚のみ、左眼は形の知覚が可 能だが視力測定不能で、盲学校に在籍していた。また 幾何学図形の視覚的な照合課題である $\mathrm{K}$ 式発達検査 の「形の弁別 I」（2歳から 2 歳 3 力月で通過）を達成 できた。

4 人の子供が要求を伝えた相手の大人はそれぞれ別 であった。A 児の相手の大人は、研究を行う半年前か ら週に 2 回各 1 時間程度個別場面だけで接触してきた 学生であった。 B 児と C 児の場合は通園施設で 1 年半 クラスを担任してきた保母、D児では盲学校の寄宿舎 で 1 年以上接触していた週 2 度勤務の非常勤寮母が相 手であった。

\section{2. 観察された伝達場面}

研究開始前に大人との 1 時間程度の個別接触を観察 し、子供が積極的に非指示身ぶり要求を伝えている活 動の中から、短時間に反復的に要求伝達することが不 自然ではないものをそれぞれ $1 、 2$ 種目選んだ。A 児で は大人にブランコを押してもらうこと及びオンブ、B 児では玉をもらって塔に入れる、レーシング・カーを もらってサーキットに乗せて走らせるという活動、C 児は自分では届かない場所においてある事物を大人に 取ってもらい、さわって楽しむ活動、D児は大人を誘つ てトランポリン上で対面して跳ぶ活動とした。それら
の活動が行われる場面を計画的に設定し、そこで生じ る要求伝達を観察した。4 組とも個別のかかわりとし た。なお $\mathrm{A}$ 児を除く 3 名では大人と子どもの間で、奏 験が行われた場面以外でも、従来通りの日常的な個別 のかかわりがあった。

\section{3. 観察の期間、場所及びビデオ録画}

それぞれの組について 8 ないし 10 週間にわたり、原 則として週に 2 度、異なる日に 1 度ずつ、20 分から 30 分程度のセッションを持つようになった。各セッショ ン内で少なくとも 10 以上の要求伝達が起きるように 計画し、大人から活動に誘う、活動を中断するなどし て伝達を誘発した。なお、A 児、B 児、C 児の 3 名は ほぼ同時期に観察されたが、D监はそれにより 2 年前 に観察された。これらは所属施設または学校内の慣れ た場所で行われた。いずれの場合もカメラマン 1 名が 約 3 メートルの距離から、両者の動きと子供の視線の 方向が判断できるよう調整して、ビデオカメラ (SONY-CCD-F500) によって録画した。

\section{4.身ぶり模倣手続きの導入}

大人には最初の 2 ないし 4 週間（ベースライン期） は、身ぶりによる要求にその大人の従来通りの方法で 応答するよう求めた。次の 4 ないし 6 週間（模倣期） は、原則として子供の要求身ぶりを模倣するよう求め た（ただし実際には模做期においても従来の応答が一 部に見られる結果となった)。

模倣は子供の要求身ぶりの直後で、かつ子供の目標 とする行動を大人が実行する直前に行うようにした。 原則として子供の要求伝達における最初の非指示要求 身ぶりを模倣するようにした。模倣のタイミングを調 


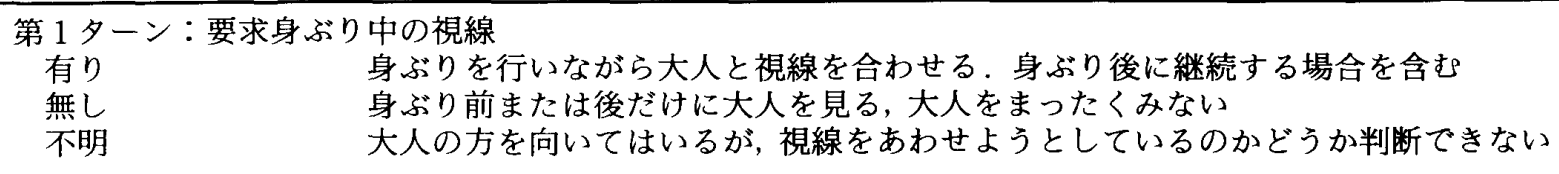

第 2 ターン：大人の応答方法

\begin{tabular}{|c|c|}
\hline 注視 & 黙ってじっと子供を見守る \\
\hline 言語 & $\begin{array}{l}\text { 言語による反応. 例「あ, ブランコか」，「ちょうだいか」．子供の身ぶりとは異なる身ぶりが } \\
\text { ともなう場合を含む }\end{array}$ \\
\hline & 指さし等の身ぶり \\
\hline 身ぶり模倣＊ & 子供の要求身ぶりの模倣. 言語をともなう場合を含む \\
\hline & 両腕を胸に当てて, 手を上に向けてクロスさせる. 言語をともなう場合を含む \\
\hline
\end{tabular}

第 3 ターン：応答に対する子供の行動

注視・言語・身ぶり模倣・その他に対する行動 無視

再身ぶり

受容の表現 無関連行動，または応答前の行動の継続，または，応答中あるいは直後に目標行動を実行しよ うとする

例 ウロウロする，あらぬ方をみる

大人を見る，大人の手をブランコにつける，大人の物を奪い取る 要求身ぶりの反復, 他の身ぶりの追加, または入れ替え 最初の身ぶりを停止し, 身ぶり前の目標行動に向かう動きを応答後に再開し, 大人による実行 を待つ

例 ブランコの綱を持って大人が押すのを待つ

応答するまで静止し，応答直後に物を受け取る姿勢をとり，大人が渡すまで手を伸ばさ ない

腕組みに対する行動

無視

あきらめ*

腕組みの変更*

直ちに大人または目標行動に関連した事物から遠ざかる

腕組みの模倣*

腕組を解かせて，大人の両手をとつて合わさせる

大人の腕組みを模做する.その後は遠ざかるか, 再度同一の大人ないし別の大人に要求する

* 模倣期においてのみ利用された分類

整するため、模倣期の最初のセッション後に筆者とそ れぞれの大人とがビデオ記録を見ながら協議した。な お $\mathrm{A}$ 児と $\mathrm{D}$ 児の相手の大人には、模倣期に数回に 1 回程度の割で任意に腕組みによる拒否を示すよう求め た。これは要求身ぶりの模做の意味を子供が理解して いるかどうかを確かめるために行われた。

研究の目的と模做の意義は D 児の相手の大人には 予め知らされていたが、結果の客観性を高めるために、 A 児、B 児、C 児の相手の大人には事前に知らされな かった。

\section{5 。資料及び分析}

ビデオ記録から非指示身ぶりによる要求伝達がみら れる筒所を抜き出し、セッションを複数の要求伝達工 ピソードに分割した。要求层達エピソードとは活動の 開始や再開を要求する子供の最初の身ぶりから、大人 が求められた動作をする、求められた物を渡すなど目 標行動を実行するまでをいう。各エピソードについて、 音声、身ぶり、視線の方向、移動や事物操作など伝達に 関連した行動を文字転写し、これを子供と大人の夕ー ンの交替として整理した資料を作成した（Table 2)。
この作業は、著者及びこれらの子供との接触がない研 究補助者とが共同で行った。一方がターンの内容と切 れ目を音声言語化し、それについて他方が同意できな い場合に協議を行い、一致した結果を文字記述した。 次にエピソード内の最初の 3 ターンに含まれる伝達行 動を Table 3 の基準により、文字転写資料とビデオ記 録を照合しながら分類した。まず筆者と補助者で子供 と大人の組毎に 1 セッションづつ協議しながら分類し た。次にそれぞれの組毎に各 1 セッションずつ独立し て分類した結果、各分類基準毎の一致度は $80 \%$ から $100 \%$ 範囲であった。その後でそれ以外のセッション について筆者が単独で分類した。1セッションは協議 して一致した分類結果を、その他のセッションは筆者 の分類結果を利用した。

結果は次のように整理した。まずベースライン期と 模做期に分けてエピソード数、ターン数、伝達行動数 を求め、さらに週毎にもこれらを数えた。これはエピ ソード数が少ないセッションがあったのと、1セッ ションしかできなかった週もあったためである。

第 1 ターン及び第 2 ターンは必ずすべてのエピソー 
大人による要求身ぶりの模倣が前言語期の重度精神遅滞児との交涉に及ほす効果

Table 4 ベースライン期と模倣期におけるエピソード数、各ターン数、及び各伝達行動数

\begin{tabular}{|c|c|c|c|c|c|c|c|c|}
\hline & $\begin{array}{r}\text { A } \\
\text { ベース } \\
\text { ライン期 }\end{array}$ & $\begin{array}{l}\text { 児 } \\
\text { 模倣期 }\end{array}$ & $\begin{array}{r}\quad \text { B } \\
\text { ベース } \\
\text { ライン期 }\end{array}$ & $\begin{array}{l}\text { 児 } \\
\text { 模倣期 }\end{array}$ & $\begin{array}{r}\text { C } \\
\text { ベース } \\
\text { ライン期 }\end{array}$ & $\begin{array}{l}\text { 児 } \\
\text { 模倣期 }\end{array}$ & $\begin{array}{r}\text { D } \\
\text { ベース } \\
\text { ライン期 }\end{array}$ & $\begin{array}{l}\text { 児 } \\
\text { 模做期 }\end{array}$ \\
\hline エピソード数（第 1,2 ターン数） & 46 & 145 & 59 & 97 & 88 & 56 & 19 & 77 \\
\hline セッション別エピソード数の範囲 & $9-23$ & $15-31$ & $10-19$ & $6-30$ & $15-32$ & $11-17$ & $9-10$ & $12-30$ \\
\hline \multicolumn{9}{|l|}{ 第 1 ターン：身ぶり中の視線 } \\
\hline 有り & 24 & 69 & 24 & 61 & 6 & 24 & 0 & 52 \\
\hline 無し & 9 & 42 & 29 & 23 & 69 & 23 & 16 & 10 \\
\hline 不明 & 13 & 34 & 6 & 13 & 13 & 9 & 3 & 12 \\
\hline \multicolumn{9}{|l|}{ 第 2 ターン：大人の応答方法 } \\
\hline 即時充足 & 13 & 0 & 50 & 7 & 29 & 4 & 7 & 0 \\
\hline 注視 & 0 & 1 & 5 & 1 & 7 & 0 & 4 & 3 \\
\hline 言語 & 33 & 2 & 4 & 2 & 52 & 4 & 8 & 5 \\
\hline その他 & 0 & 13 & 0 & 0 & 0 & 0 & 0 & 0 \\
\hline 身ぶり模做 & 0 & 112 & 0 & 87 & 0 & 48 & 0 & 55 \\
\hline 腕組み & 0 & 17 & 0 & 0 & 0 & 0 & 0 & 14 \\
\hline \multicolumn{9}{|l|}{ 第 3 ターン：子供の伝達行動* } \\
\hline ターン数** & 33 & 112 & 9 & 87 & 59 & 48 & 12 & 55 \\
\hline セッション別ターン数の範囲 & $8-18$ & $11-26$ & $3-6$ & $6-27$ & $10-19$ & $9-15$ & $6-6$ & $5-20$ \\
\hline 無視 & 8 & 7 & 3 & 9 & 8 & 20 & 3 & 0 \\
\hline 再身ぶり & 14 & 26 & 6 & 36 & 51 & 12 & 9 & 5 \\
\hline 受容の表現 & 11 & 79 & 0 & 42 & 0 & 16 & 0 & 50 \\
\hline
\end{tabular}

*腕組みに対する子供の伝達行動は別にTable 5に示した

**ベースライン期では, 注視, 言語, その他の合計数に，模做期では身ぶり模做数に等しい。な扔模做期における注視，言語，その 他の応答に対する子供の各伝達行動の頻度は本文中に記した

ドに含まれるので、それぞれの数はエピソード数に等 しい。第1ターンでは身ぶり中の視線の出現率（身ぶ り中の視線有りのターン数/エピソード数）を算出し た。第 2 ターンは各伝達行動を数えた。なお身ぶり模 做と腕組みはベースライン期には存在しない。

第 3 ターンは第 2 ターンが即時充足であるエピソー ドには存在しない。以下の理由によりべースライン期 と模倣期とで整理の方法は異なる。ベースライン期に は腕組みがないので第 3 ターンは無視、再身ぶり及び 受容の表現の 3 つのいずれかとなる。模倣期では第 2 ターンが身ぶり模倣、注視、言語、「その他」の場合、 第 3 ターンは無視、再身ぶり及び受容の表現のいずれ かとなり、第 2 ターンが「腕組みの場合は、無視、あ きらめ」腕組みの変更、腕組みの模倣のいずれかとな る。次に無視、再身ぶり及び受容の表現のそれぞれの 出現率（特定伝達行動数/第 3 ターン数）を算出する際 は、ベースライン期では第 2 ターンが即時充足でない エピソードの数を第 3 ターン数とし、模倣期には分母 となる第 3 ターン数を、第 2 ターンが身ぶり模倣で あったエピソード数とした。これはベースライン期の
第 2 ターンが通常の応答である場合と、模倣期で導入 された身ぶり模做の場合との第 3 ターンにおける子ど もの伝達行動の違いをみるためである。なお模做期の 第 2 ターンが言語、注視、「その他」であるエピソード の、第 3 ターンにおける各伝達行動の出現頻度は別に 数えた。最後に模倣期では、第 2 ターンが腕組みであ るエピソード数、腕組みに対する各伝達行動の出現頻 度を求めた。

\section{III. 結 果}

ベースライン期と模倣期それぞれにおけるエピソー ド数、各ターン数、及び各伝達行動数を Table 4 に、 第 3 ターンにおける子供の各伝達行動の出現率の時間 的な変化を Fig. 1 に、第 1 ターンの要求身ぶりにおけ る大人への視線の出現率の時期的な変化を Fig. 2 に、 模做期に打ける大人の腕組みとそれに対する子供の各 伝達行動の出現頻度を Table 5 に示した。

\section{1. ベースライン期}

第 2 ターンにおける大人の伝達行動の内訳は Table 4 の通りである。第 3 ターンは B 児、C 览、D 児では子 

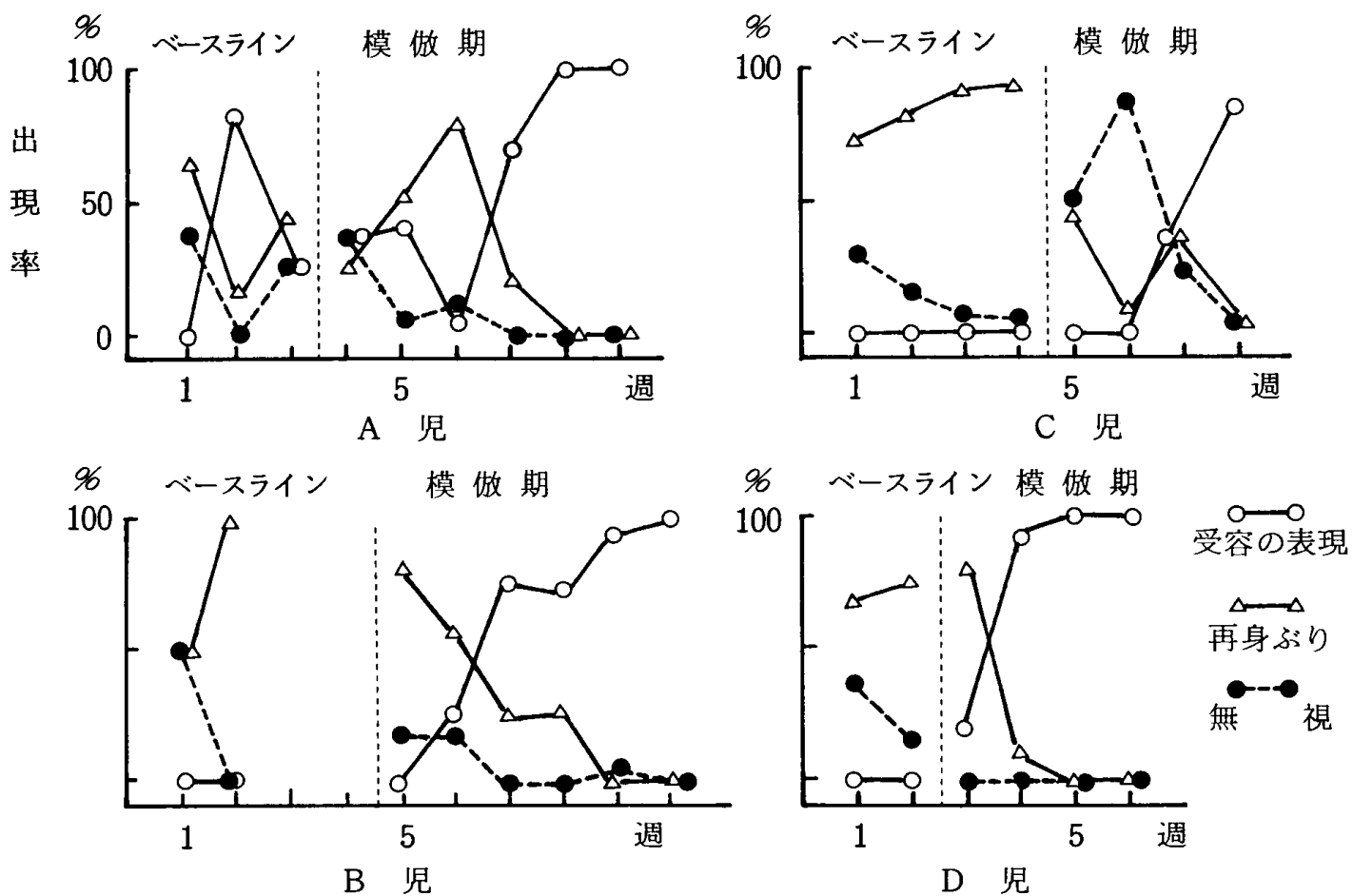

Fig. 1 要求身ぶりへの大人の応答に対する子供の無視、再身ぶり、 及び受容の表現の出現率の時期的な変化

A 児の第 2,3 週における,受容の表現はすべて「いいよっという大人の言語応答に対して見られた。 パーセントの値は，(第 3 ターンの特定伝達行動数／第 3 ターン数 $\times 100 ）$ の式で算出した. な お第 3 ターン数は, ベースラインにあっては第 2 ターンが即時充足でないエピソードの数とし, 模做期では第 2 ターンが身ぶり模倣であるエピソードの数とした
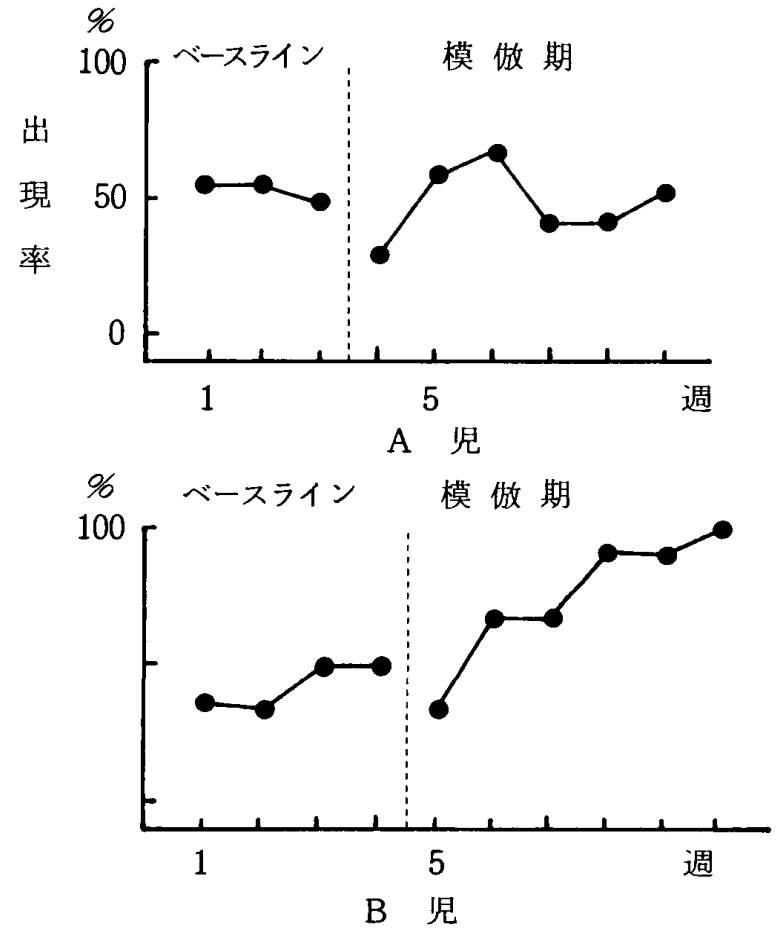
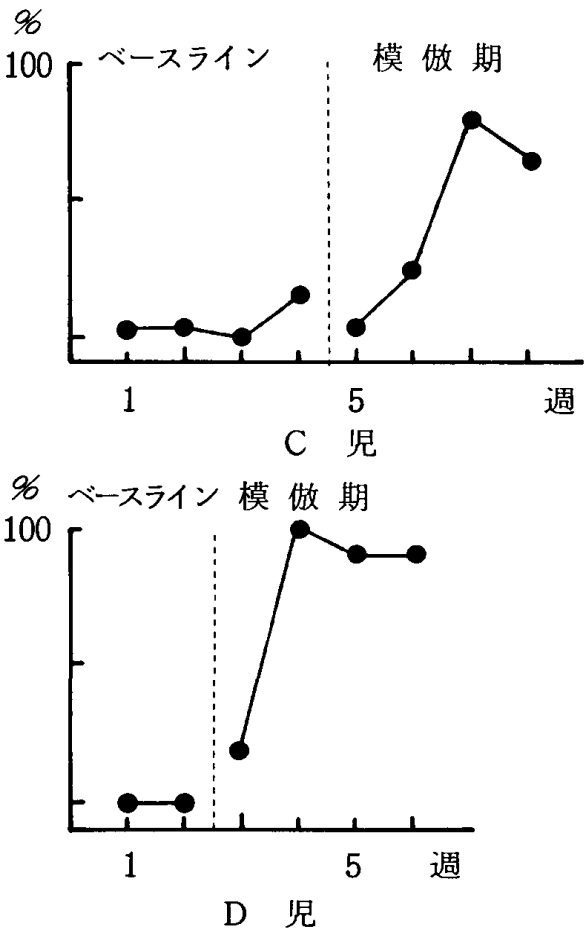

Fig. 2 要求身ぶり中の大人への視線の出現率の時期的な変化

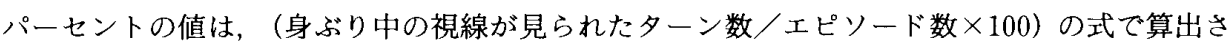
れた 
Table 5 模倣期の腕組による拒否に対する 子供の反応

\begin{tabular}{|c|c|c|c|c|c|c|c|c|c|c|}
\hline & \multicolumn{6}{|c|}{ A } & \multicolumn{2}{|c|}{$\mathrm{D}$} & \multicolumn{2}{|c|}{ 児 } \\
\hline & 週 4 & 5 & 6 & 7 & 8 & 9 & 3 & 4 & 5 & 6 \\
\hline 大人の腕組数 & 0 & 2 & 3 & 3 & 5 & 4 & 3 & 0 & 2 & 9 \\
\hline \multicolumn{11}{|l|}{ 子供の伝達行動数 } \\
\hline 無視 & 0 & 2 & 2 & 2 & 1 & 0 & 0 & 0 & 0 & 0 \\
\hline あきらめ & 0 & 0 & 1 & 1 & 2 & 0 & 1 & 0 & 0 & 0 \\
\hline 腕組の変更 & 0 & 0 & 0 & 0 & 2 & 4 & 2 & 0 & 0 & 0 \\
\hline 腕組の模做 & 0 & 0 & 0 & 0 & 0 & 0 & 0 & 0 & 2 & 9 \\
\hline
\end{tabular}

数字は出現頻度を示す

供からの受容の表現がまったくみられず、再身ぶりが 多く、無視が若干あった (Table 4)。A 児で 33 の第 3 ターンのうち 11 で受容の表現がみられた。事後的に大 人の発話内容をみると、受容が表現されたのはすべて 「いいよ」という発話に対してで、13 回の「いいよ」 中11 回がそれであった。「いい」以外の「してほし い」などの発話は、20 回すべてが無視または再身ぶり であった。なお B 児、C 児、D 児では「いいよ」とい う応答は行われなかった。

第 1 ターンにおける身ぶり中の大人への視線は、A 児と B 児とで約半数のエピソードでみられ、C 児はご くわずかしかなく、D 児は皆無であった（Table 4）。

\section{2 . 模倣期}

第 2 ターンにおける大人の伝達行動の内訳は Table 4 に示した。第 3 ターンにおける受容の表現の割合は 4 名ともべースライン期に比べると模倣期は著しく多く なった（Table 4)。その出現率の時期的変化を見ると 4 名とも最終週には約 $90 \%$ から $100 \%$ に達し、再身ぶ りと無視は 0 ないし $5 \%$ に減少した。B 児、C 児、D児 の 3 名では、ベースライン期に 0\%であったのが模倣 期に約 90\%から 100\%に達するという明確な時期的変 化が示された（Fig. 1)。A 児にお汀る時期的な変化は 3 名ほど明確ではないが、模倣期後半の 3 つの週でみ ると身ぶり模倣がされた 74 エピソードのうち 69 で受 容が表現されており、ベースライン期計 3 週 33 エピ ソード中 11 よりも割合が高かった。なお第 2 ターンが 言語、注視及び「その他」であるエピソードの第 3 ター ンの内訳は、A 児は 16 のうち無視 4、再身ぶり 10、受 容の表現 $2 、 B$ 児は 3 のうち無視 2、再身ぶり 1、C 児 は 4 のうち無視 $1 、$ 再身ぶり 3、D 巟は 8 のうち無視 $2 、$ 再身ぶり6であった。A児の受容の表現はいずれも 「いいよ」に対するものであった。
第 1 ターンの身ぶり中の視線が有りの割合は B 児、 C 児及び D 児ではべースライン期にくらべ多くなっ たが、A 児では変化がなかった（Table 4)。その出現 率の時期的変化をみると、B 児、C 児、D 児では最終週 に約 70\%から 100\%に達したが、A 児では模做期に 入っても増加しなかった（Fig. 2)。A 児における身ぶ り中の視線が不明の割合はベースライン期と模倣期と で差がなかった。また模倣期前半の 3 つの週で 52 エピ ソードのうち不明 11、後半の 3 つの週で同じく 93 の うち 23 となり、模做期内でも変化しなかった。

\section{3. 腕組みに対する子供の伝達行動}

Table 5 に示したように、A 児は腕組みが導入され た第 5 週から第 7 週までは、それに対して無視または あきらめのどちらかであった。第 8 週には腕組みの変 更が 2 回見られ、第 9 週はすべての腕組みが変更され た。腕組みの模倣は見られなかった。D览は腕組みが 導入された第 3 週はあきらめまたは腕組の変更、第 $5 、$ 6 週はすべて腕組みの模倣であった。

\section{IV. 考 察}

\section{1. 身引氵り模倣による受容の表現の促進}

ベースライン期では大人の応答に対する受容の表現 が、4名のうち 3 名でまったく見られなかった。A児だ けは「いいよ」という応答に限り受容を表現したが、 その割合をべースライン期全体でみると、第 3 ターン を有する要求伝達エピソード合計数の 3 分の 1 にとど まっていた。したがって、非指示身ぶりによる要求伝 達に対して大人が通常のやり方で応答した場合、それ に対する受容を表現することは 4 名の子供達にとって 困難であるといえる。大人の応答は $\mathrm{A}$ 児ではすべて言 語であり、B児、C児、D児でも半分ないしそれ以上が 言語で占められていた。4 名の子供達は、大人が言語的 に提供する解釉の意味や、確諗を求める発話の目的を 理解できず、受容の表現に至らなかったものと思われ る。

子供の要求身ぶりを大人が模倣するようにすると、 4 名ともそれに対する受容を表現するようになり、模 做期の終わりにはほとんどすべての要求伝達エピソー ドで受容が表現されるに至った。B児、C览、D览では ベースライン期になかった新しい伝達行動が形成され たことになる。また A 児でも受容を表現する割合は ベースライン期に比べて増加している。なお、模做期 に一部見られた言語などの通常の応答に対しては、 ベースライン期同様に受容が表現されなかった。大人 からの要求身ぶりの模倣が導入されたことによって、 
4 名とも受容の表現が促されたといえる。

これらの子供達は要求身ぶりの模做が要求に対する 肯定を意味することを理解するに至ったものと考えら れる。大人がときどき腕組みで要求を拒否した 2 名の 子供のそれに対する反応の変化過程からも、身ぶり模 做が肯定を意味することの理解が確実になっているこ とがうかがわれる。A児は初め腕組みを無視して大人 に目標行動を実行させようとしたが、やがて腕組みを やめさせ両手吒き身ぶりの模做を促すようになった。 D 览は初めあきらめて要求を中断するか、腕組みをや めさせ合掌させようとするかであり、後には腕組みを 模做するようになった。2人とも要求身ぶりの模倣と 腕組みとの意味的な違いを徐々に弁別するようになっ たものと考えられる。

\section{2. 身ぶり中に大人を見ることの意味}

ベースライン期では C 児と D 児はほとんど身ぶり の際に大人を見ず、A 児と B 児は約半数のエピソード で大人を見ながら身ぶりしていた。大人が身ぶりを模 倣するようにすると、C 児とD 児では大人を見ながら 身ぶりをすることが著しく増加し、B 児でも大人を見 ながら身ぶりする割合が、模倣期の終わりにはべース ライン期の約 2 倍に増加した。しかし A 児ではその割 合が変化せず、また大人の方を向いているが視線を合 わせているかどうか不明である割合も変化しなかっ た。A児を除く 3 名では受容の表現と大人を見ながら 身ぶりすることとがほほ平行して増加しており、大人 を見るのは要求身ぶりを模做するかどうか確かめるた めであることが示唆される。A 児において模做期に大 人を見ながら身ぶりすることが増えなかった理由はよ くわからない。A児は身ぶり模倣に対し受容を表現 し、また腕組と身ぶり模做とを区別していたので、大 人の身ぶりそのものは見ていたと考えられる。

\section{3.まとめ}

大人による要求身ぶりの模做は、 4 名の子供の大人 とのコミュニケーションを大きく変えた。身ぶり模倣 が導入される前にも、子供の伝達、大人の応答、再び 子供の伝達という 3 ターンからなるパタンは存在し た。大人も子供も互いに協力し合おうとはしていたと 考えられる。しかしそれは Golinkoff $\left(1986^{21}\right)$ の示し たものとはまったく異っていた。子供は大人の応答を 確かめようとするようすが乏しく、身ぶり模做が導入 された後に比べ大人を見ながら身ぶりすることが少な かった。大人の言語応答は子供にとって理解が難しく、 関心を払うべき対象ではなかったものと考えられる。 言語応答に対しては、大人に目標行動を実行させよう
とするか身ぶりを反復するかしかなく、受容を表現で きなかったものと思われる。

子供の非指示要求身ぶりを大人が模做することに よって、3ターンからなる協力のパタン、すなわち子供 の伝達、大人の解釈の提供、子供の受容の表現という 最小限の交涉が成立するようになった。これは Golinkoff $\left(1986^{2)}\right)$ が障害を持たない 12 力月児の母親に対 する伝達において見いだした第 1 のパタンに非常に近 い。違う点は大人からの解釈の提供が言語ではなく、 要求身ぶりの模做によってなされる点である。非指示 要求身ぶりを大人が模做するということは、普通のコ ミュニケーションの習慣には見られないようであり、 4 名の子供に対してもべースライン期ではまったく行 われなかった。それは非常に特殊な伝達行動といえる かもしれない。しかし語用論的には特殊なものではな く、会話の規則に子供を導こうとする大人の試みであ る点において、12 力月児に対する母親の言語応答 $\left(\right.$ Golinkoff $\left.{ }^{2}\right)$ と共通である。

なお、得られた結果の大人と子供の組による違いに 対して、子供の発達差や模做期における大人からの腕 組による拒否の有無がそれぞれどのように影響してい るかは明かでない。

本研究の結果は、非指示身ぶりによる重度精神遅滞 児の要求伝達について、大人との最小限の交涉が成立 しているかどうか、及び子供の要求身ぶりに対する大 人の模倣が交涉の成立にどのような効果を及ぼすかと いう 2 つ問題を、より広い視野から検討することの 重要性を示している。まず、通常は言語によっている 大人の応答に対して受容を表現するのが困難だという 問題が、非指示身ぶりを主たる要求伝達手段とする、 より多数の重度精神遅滞児においても示されるのかど うか、またそれが伝達を誘発すべく計画された場面だ けでなく、日常の自然な伝達場面においても示される かどうか明らかにする必要がある。次に、大人による 身ぶりの模做が子供の受容の表現を促し、交涉を成立 させるという効果が、非指示身ぶりで要求を伝える重 度精神遅滞児に一般的に期待できることなのか、また 計画された伝達場面において見られた大人の身ぶり模 做の効果が、日常の自然な伝達場面にも般化し、長期 的に維持されるものなのかどうかについて明らかにし なければならない。

\section{謝 辞}

本研究の実施において次の方々の協力を得ました。 記して謝意を表します。東 晶子、朝倉慶子、森田乃 
里子、奥出順子、竹田睦月、打本裕美子、善家陽子の 各氏。また研究の機会をお与え下さった保護者、施設 及び学校の皆様、そしてなによりも研究に参加してく れた子どもたちに深く感謝します。

\section{文 献}

1) Bruner, J. S. (1983) Child's Talk-Learning to Use Language. Oxford University Press. 寺田 晃・ 本郷一夫訳 (1988) 乳幼児の話しことばーコ ミュニケーションの学猊. 新曜社.

2) Golinkoff, R. M. (1986) "I beg your pardon?" The preverbal negotiation of failed messages. Jounal of Child Language, 13, 455-476.

3) 木下孝司 (1987) 乳幼児における要求伝達手段の 調整過程一聞き手からのフィードバックとの関 連で一。教育心理学研究, 35, 351-356.

4) Levinson, S. C. (1983) Pragmatics. Cambridge University Press. Cambridge. 安井 稔 - 奥田 夏子訳 (1990) 英語語用論. 研究社出版.

5) McLean, J. E., McLean, L. K. S., Brady, N. C., and Etter, R. (1991) Communication profiles of two types of gesture using nonverbal persons with severe to profound mental retardation. Journal of Speech and Hearing Research, 34, 294-308.
6) McReynolds, L. V. and Kearns, K. P. (1983) Single -Subject Experimental Designs in Communicative Disorders. Pro-Ed., Austin TX. 西村辨作・ 小塩允護訳 (1989) 言語障害の実験研究法一心 理・言語臨床家のために. 学苑社.

7) McTear, M. F. and Conti-Ramsden, G. (1992) Pragmatic Disability in Children. Whurr Publishers Ltd. London.

8) Miller, J. E., Chapman, R. S., Branton, M. B., and Reichle, J. (1980) Language comprehension in sensorimotor stage V and VI. Journal of Speech and Hearing Research, 23, 284-311.

9) 大井学 (1990) コミュニケーション障害児への 語用論的アプローチについて．日本特殊教育学 会第 28 回大会発表論文集, S22-S23.

10）大井 学 (1992) 大人との交涉を通じた重度精神 遅滞児の前言語的要求伝達の改善. 特殊教育学 研究, 30 (2), 33-44.

11) Tomasello, M, Conti-Ramsden, G., and Ewert, B. (1990) Young children's conversation with their mothers and fathers: differnces in breakdown and repair. Journal of Child Language, 17, 115 -130 .

- 1992.6.22. 受稿, 1993.9.4. 受理一 


\title{
Effects of Adult's Immitation of Children's Communicative Request Gestures on Communicative Behavior of Prelinguistic Children with Severe Mental Retardation
}

\author{
Manabu OoI \\ Faculty of Education, Kanazawa University \\ (Kanazawa-Shi, 920)
}

The effects of adult gestural monitoring on the communicative behavior of prelinguistic children with severe mental retardation were investigated. Gestural monitoring occurs when an adult imitates a child's gesture that request an object or action.

Four adult-child dyads participated in this study, which used a single subject multiple baseline research design with a few weeks' baseline and several weeks' treatment. The children, all boys, ranged from 5 to 9 years in age ; they were likely to make requests with non-indicative gestures, such as folding their arms or clapping. Their communicative behavior in the baseline period was compared with that in the treatment period.

Three hypotheses were examined. First, it was assumed that the children would not accept what the adults offered verbally in response to the children's request. Second, it was expected that the adults' gestural monitoring would be accepted by the children, and, third, it was also expected that an increase in the children's gazing at the adult while they were gesturing would parallel the children's expression of their acceptance.

The results supported the hypotheses with a few exceptions. The results in the baseline period were as follows : Three of the children never expressed acceptance, but were likely to imitate the adults' gestures or ignore the adults' verbal responses. The fourth child expressed acceptance in a third of trials. Two of the children hardly looked at the adult while they were gesturing, whereas the other two looked at the adult during half of their gestures.

In the treatment phase, the rates of expressing acceptances increased for all children, reaching $90 \%-100 \%$. The rate of looking at the adult also increased for three of the children during treatment phase, reaching $90 \%-100 \%$, whereas for the fourth child, it did not change from baseline to treatment.

Thus, a pattern of adult-child communicative cooperation was established in all the dyads. This pattern consisted of the follwing three parts; the child's initial gesture, the adult's gestural monitoring, and the child's acceptance of that. This pattern greatly resembles what Golinkoff (1986) found in communications between 12month-old infants without disabilities and their mothers.

Further investigation is required to determine whether these results could be replicated in a larger number of dyads composed of a prelinguistic child with severe mental retardation and an adult.

Key Words : prelinguistic communication, request gesture, interaction, children with severe mental retardation 